大規模地形改変の全国的把握

\author{
田村俊和 $*$. 山本 博**.吉岡慎一 $* * *$
}

\begin{abstract}
各種用地の大規模開発に伴い, 地形が人工的に直接作り変えられることに端を発して, 土地・自然の一部 または全体が変化することを大規模土地改変と呼ぶ.これを人工地形学的に研究する枠組みを提示し，当面 最も必要とされる，地形改変の実態を把握する手法について検討した．基礎的な統計資料が整備されていな い現段階では，少数の代表例についての大縮尺的な資料とともに，各開発目的ごとの中地形別開発面積の年 次変化が，大規模地形改変の動向を把握するのに有効な鍵となることがわかった. これを用いて解析した結 果, 日本各地で1960年頃から直接的地形改変の規模が飛躍的に增大したこと, それによる人工的な土の移動 を広域的にとらえたときの平均的な速度は, 自然状態での削剝速度の数倍 数百倍に達するようになったこ と，およびそのような規模・速さの増大が，地形利用傾向の著しい変化（低平地中心から丘陵地, 低山地を も含む）とともに進行したこと，などが明らかとなった。
\end{abstract}

\section{I 大規模土地改変現象と人工地形学}

地形形成に対する人間の介入という問題は, 近代 科学として地形学が成立した頃にはすでに注目され ていた（たとえば Marsh, 1864; Sherlock, 1923 な ど)。しかし，その体系的研究は，東欧の一部を除 けば，決して活発に続けられてきたとはいえない ようである(Haigh, 1978). その東欧での研究のひ とつの集約として，Z Zapletal(1973) ${ }^{1}$ は，人工地形 学(anthropogenic geomorphology) を「人造地形 (man-made landforms) と人為誘導地形 (man-induced landforms) との両方についての, 地理的分布 特性の解明, 地形分類, およびその生成・発展・消 滅にかかわるプロセスの研究」と定義した。 ここで 人造地形とは, 人工の直接の作用で, 自然の地形が 部分的に, 多くの場合人間の意図どおりに, 作り変 えられて生じた地形をさす.これに対して人為誘導 地形とは, 人為の影響をいろいろな程度に受けては いるがあくまでも自然の地形形成作用によって作り 出された地形のことである.

この 2 つうち, 純粋地形学の延長上で扱いやす いのは, いうまでもなく後者で, 観測・実験的研究 * 東北大学 - 教養部 ** 北海道大学 - 環境科学研 究科 $* * *$ 東京都立大学・院
例の多い土袞侵食(人為的加速侵食)がその好例であ る. 地形学における人間の作用の研究を, この人為 誘導地形についてだけに限ろうとするかのような見 解もしばしばみられる(たとえばTwidale, 1968). しかし, 地形学がさまざまな地形の, 形態, 構成物 質, 形成過程, 年代などを扱了以上, 人造地形の研 究を等閑視することはできない. 東欧での人工地形 研究においても，たとえばDemek (1973)は，人造 地形あるいはその形成過程の地形学的評価を積極的 に行なおうとしている.とくに，近年の日本のよう な状況においては, 住宅用地, 工業用地, 農用地, レクリエーション用地などの大規模開発に伴って地 形が直接的に大きく改変される現象は, 地形変化の 速さ, 出現する地形の形態・構成物質の特異さ, そ の空間的広がりの大きさ，および関連する土地自然 全体の変化がもたらす広義の環境問題》の多様さな どの点で, 地形学的に大いに注目すべきものである. したがって，各種の大規模開発行為にかかわる上記 の現象全体を大規模土地改変現象と呼べば，その発 端となる大規模地形改変こそ, 現代日本の人工地形 学における第一級の研究対象といえよう(Tamura, 1976; Kadomura, 1980).

ところで, 地形学では一般に, 直接的な地形形成 作用（たとえば侵食・堆積や隆起・沈降・断層運動 
などのプロセス）だけでなく，背後にある地形形成 環境とその地域的・時代的変化にも言及する．たと えば, 気候地形学では気候の, また変動地形学では 地款変動傾向の, それぞれ地域的・時代的差異をも 論しる. 人工地形学において, とくに人造地形を対 象とする場合, 地形形成環境に相当するのは, 一存 の自然地形の諸特性のほか, 社会・経済情勢, 建設 技術, 法的 - 行政的規制, さらには文化的・歴史的 慣習などであろう．これら自然的・非自然的諸要因 の地域的・歴史的変化が, 人造地形形成作用（たと えば切土・盛土の規模・様式など）の違いを通じて， 人工地形の分布や形態の差異をむたらしていると考 えられる。

筆者らは, 日本地理学会人工地形作業グループの 他のメンバーとともに，現代日本における大規模土 地改変現象を, 上述のような枠組みでとらえようと している. 今回は, その第一歩として, 大規模地形 改変の実態を把握する手法について検討し，その手 法で得られた，全国スケールならびに都市圈スケー ルでの大規模地形改変の展開状況 ${ }^{33}$ を提示し, さら にそれについての考察の䋊をを示唆する.

\section{II 資料の整備と活用}

1）基礎資料の整備状況とその活用の方策

大規模地形改変を論しるのに必要な, 最も基礎的 な情報は，「どのような地形が，何のために，いつ， どのくらいの規模で, どのように改変されたか」に 関するものである(田村, 1982)。このような情報は, 根本的には, おのおのの用地開発事業の計画書に示 されている、そこには, 造成地の位置, 造成主体, 造成の目的, 造成期間, 経費などが明示されるとと むに, 造成前後の地形を示す縮尺 500 分の 1 から 1,000 分の 1 程度の等高線図が付されていて, 人工 的地形改変状況を微地形スケール4) で検討できる. 改変に伴う切土量・盛土量も, その四からかなりの 精度で算定でき, 普通はすでに計測・表示されてい
る.これに, 空中写真判読, 現地踏査, ボーリング 資料解析などによって得られる, 植生, 土地利用, 土壌, 表層地質などに関する情報が付け加われば, 地形改変現象の一次資料としてほぼ完全になる。

個々の造成地で生じる個別の現象) に注目する場 合には，このような一次資料を用いることが不可欠 である.しかし，かなり広い地域にわたって大規模 地形改変をとらえようとするとき，しばしば膨大な 量にのぼり，しかも散在する上記のような一次資料 の集積を待つだけでは，実用的ではない(6)。一方， 広域にわたる地形改変関連資料として, 普通入手可 能なのは用途別・行政区画別の開発面積と，せいぜ い小縮尺の分布図程度であり, それらは直接的に地 形改変状況を示すものではない?. そこで, 必要な 情報の種類を備えている比較的少数の一次資料と, 地域的には網羅するが, 位置と面積程度の項目しか 有用でない集計資料とを効果的に併用し，外挿法で 妥当な数值を求め, 地域的動向などを推定すること が考えられる. その際に, 地形改変様式を適切に類 型化して和くことや, 改变規模を示す有効な指標を 設定することなどが必要になる。

地形改変様式は，さまざまな視点から分類でき， その多くは造成工法と対応するが, 基本的には改変 目的(用途) と改変地の地形的立地で規定されている とみてよい. 改変地の用途や改変前の地形をどの程 度細かく分類するかは, 調査対象地域の大きさや調 査目的によって異なる.たとえば，隣接する数個所 の宅地造成地で, その内部の改変状況の地域的な相 異を議論する場合には, 集合住宅用地か戸建住宅用 地かの分類が必要である.さらにこの場合, 地形に 関しては, 小地形スケールの地形の違いを連続的な 地形計測量で表示する必要があろう。一方, 全国あ るいは都市圈のスケールで各種開発行為をあわせて 取り扱う場合には, 用途分類は住宅用地, 工業用地, 農用地などの程度でよく，後述のことを考えあわせ ると, 地形も中地形スケールで分類しておくのが適 
切なように思われる。

改変規模を示す指標も, 対象地域の大きさによっ て必ずしも一様ではない，一般に，小地域を大縮尺 的に扱う場合ほど, 個々の地形改変過程を的確に反 映するパラメータの設定が求められる. 大地域を小 縮尺的に扱う場合には，上述の利用可能な資料の制 約を考慮した，多少とも妥協的な指標設定を余儀な くされがちである. 地形改変規模を端的に示す比較 的簡便な指標として, 二次元的には改変面積, 三次 元的には土工量のようなものがあげられる. 比較的 簡便とはいってもこれらの值を, 公刊されている中 縮尺地形図類から直接計測することは, 等高線間隔 や改測年次の間隔と地形改変の実態とを考え合わせ てみれば，かなり困難なことがわかる8．

そこで，中地形を基本的な単位に，開発目的ごと

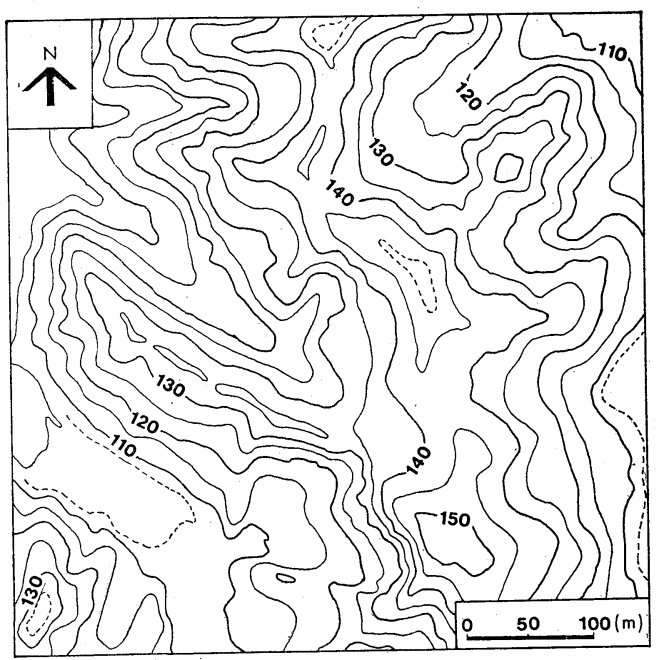

に標準的な改变規模を一次資料から求め, 一方では, 広域にわたる集計資料と小縮尺分布図から，中地形 別改変面積を開発目的ごとに求めておいて，この両 者から広域の改変規模を推算することが考えられる. 改変規模に関与する自然的要因は, 起伏量 - 谷密度 などの地形計測的なものと地形構成物質とであるが， 中地形の違いはそれらの違いとかなりょく対応する (Tamura, 1981, Fig. 1). さらに加えて，広域的に みれば，各中地形はそれぞれ卓越する1 2の土地利 用と対応するので9)，土地改変現象に対する土地利 用の側面からの検討にも道を開く. したがって, 各 種用地開発の中地形別面積は, 大規模土地改変現象 を広域的にとらえる際の, 簡便で, かなり的確な指 標となる.

\section{2）大縮尺図でみた大規模地形改変の典型例}

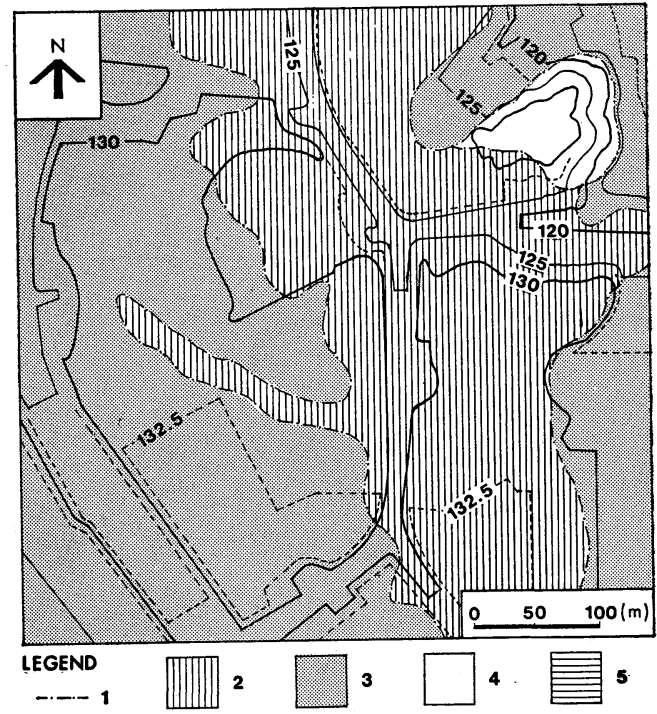

b. 改変後の地形

a. 改変前の地形

第 1 図丘陵地における大規模住宅地開発による地形改変の例 (多摩ニュータウン)

1. 切土・盛土の境界 2 . 切土域 3 . 盛土域 4 . 自然地形域 5 . 水面.

第 2 図, 第 3 図も同様.

Fig. 1 Typical landform modification due to large-scale residential development in the hills. An example of Tama New Town in the Tama Hills, west of Tokyo

$\mathrm{a}$ : landform before modification $\mathrm{b}:$ landform after modification 1. boundary of artificial cut zone and fill zone 2. artificial cut zone 3. artificial fill zone 4. not-modified zone 5 . river and pond. 
上述のような考えに基づき，全国，あるいはいく つかの都市圈について, 地形改変規模を推算する準 備として, 用途別・中地形別にいくつかの典型的な 地形改変状況を大縮尺図でみておく.

\section{1. 住宅用地開発}

大規模住宅用地開発は, 現在, 低山地, 丘陵地, 台地, 低地, さらには海面埋立地で進行している。 第 1 図に示すのは丘陵地での大規模住宅用地開発に 伴う地形改変の例である. 風化火山灰層, 中部更新 統風化砂層, および下部更新統半固結堆積岩からな る比高約 $40 \mathrm{~m}$ の稜線部では最大 $20 \mathrm{~m}$ の切り取りが, 厚さ $2 \sim 3 \mathrm{~m}$ の軟弱な堆積物をもつ谷底部では最大 25 $\mathrm{m}$ の盛り上げが行なわれて，公園予定地の一部を除 けば，域内に自然の地表面が残らない，図示した範 团を含むこの工区全体(約 $350 \mathrm{ha}$ ) で，切土総量は 約 $1,4 C 0$ 万 $\mathrm{m}^{3}$, 盛土総量は約 1,440 万 $\mathrm{m}^{3}$ に達する. 切土の大半は，原則として同一工区内の盛土に用い られるので, 上記の切土量・盛土量をたしあわせる ことは，二重の見積りをすることになる．そこで両

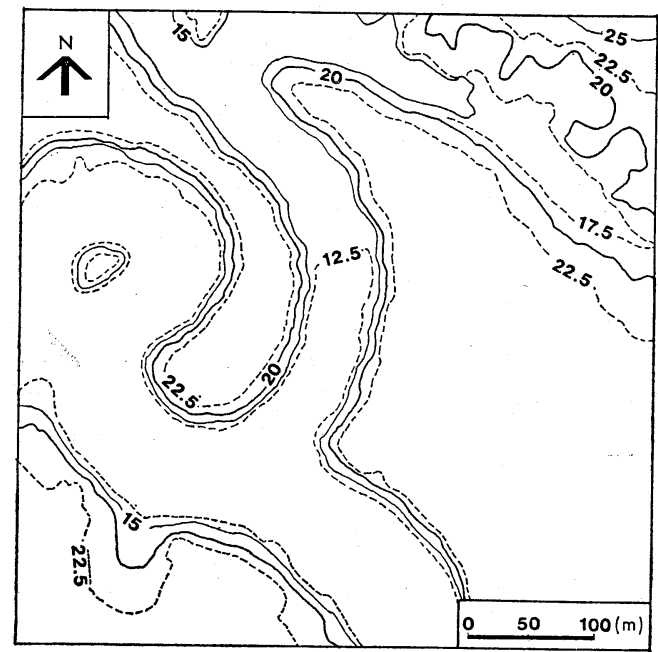

a . 改変前の地形
者のうち，大きな方の值を「移動土量」と呼び，そ れを改変面積で除した值を「平坛表層攂乱深」と名 づける. この值は,ここに図示した宅造地では 4.1 $\mathrm{m}$ である. 首都圈のいくつかの例からみて，丘陵地 での大規模住宅用地開発に伴う表層攪乱深の平均的 な值は，4 $\mathrm{m}$ 程度と見積られる(武内・吉岡，1982）。 このような，中地形別にみた場合の大規模開発地に おける平均的な表層攪乱深を「標準表層攪乱深」と 呼ふ.

第 2 図は, 開析のやや進んだ台地での大規模宅地 開発に伴う地形改変の例である. 第 1 図と比べて, 自然の地表面が多く残され，切土深・盛土厚とも小 さいので, 改変面積 (345 ha) の割に移動土量が少な く $\left(960\right.$ 万 $\left.\mathrm{m}^{3}\right)$, 作図地域を含めた区域での平均表層 攬乱深は $2.8 \mathrm{~m}$ と小さくなる。開析のあまり進んで いない台地では，この值はもう少し小さくなり，た とえば第 2 図と同じ龍ヶ崎ニュータウン内において も, 開析谷を多く含まない地域での平均表層攪乱深 は $1.5 \mathrm{~m}$ 程度を示している.こうして首都圈内の事

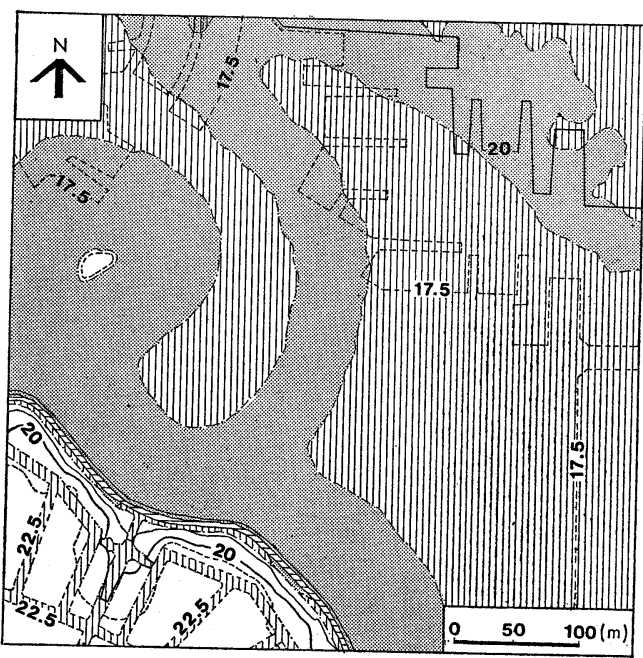

b. 改変後の地形

第2図台地における大規模住宅地開発による地形改変の例 (龍; 崎ニュータウン)

Fig. 2 Typical landform modification due to large-scale residential development in the terraces. An example of Ryugasaki New Town in the Joso upland, northeast of Tokyo

See Fig. 1 for legend. 
例から, 台地での大規模住宅用地開発に伴う標準表 層擤乱深は $2 \mathrm{~m}$ 程度と推定される. 同様にして, 低 地では $1 \mathrm{~m}$, 大起伏丘陵地ないし低山地では $5 \mathrm{~m}$, 埋立地では $10 \mathrm{~m}$ の標準表層描乱深が，いずれも首都 圈での大規模住宅用地開発例から求められる(武内・ 吉岡，1982)．もちろん，低地・埋立地の標準表層 鹠乱深は，ほとんど盛土によるものである．これら の数值は, 開発域内での移動土量から計算したもの で, 開発域外の土取り場, しゅんせつ地等の面積・ 土砂採取量については計算に入れていない.

\section{2. 農用地・その他の開発}

第 3 図は，鮮新統からなる丘陵地での大規模畑地 造成に伴う地形改変の例である. 元の地形の傾斜は, 丘腹斜面で $30 \sim 45^{\circ}$, 起伏量は $40 \sim 50 \mathrm{~m}$ 程度であっ たが，最大約 $25 \mathrm{~m}$ の切り取りと約 $23 \mathrm{~m}$ の盛り上げ によって，周囲に急斜部をもつ傾斜 $5 \sim 6^{\circ}$ のほぼ一 様な緩斜面に作り変えられた。 このように,ここで は類似の地形条件の所で行なわれる宅地造成の場合 とほぼ同程度の規模の地形改变が行なわれている.

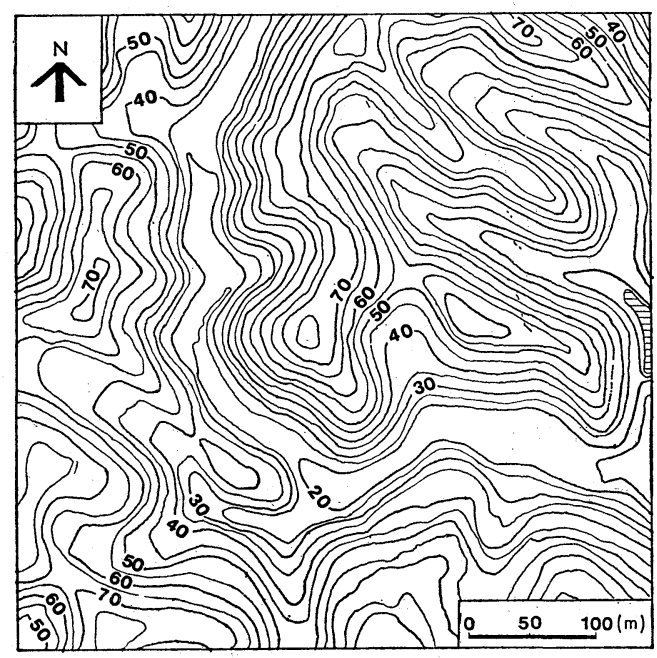

a. 改変前の地形
水田造成の場合, 開析の進んだ台地における例（大 石，1982）では，最大切土深，最大盛土厚はいずれ も約 $5 \mathrm{~m}$ ，標準表層攪乱深は約 $1.4 \mathrm{~m}$ と，類似の地 形条件の所で行なわれる宅地造成の場合の半分程度 である。

工業用地造成による地形改変の規模については, 上述のような大縮尺図に基づく具体的検討がまだ不 十分であるが，利用する地形が同じならば，住宅用 地造成の場合とほぼ同程度とみてょいようである. ゴルフ場造成による地形改変は，普通に想像される より大規模であるが，それでも小林(1978)の整理し た例などからみると，平均表層攪乱深を目安にして， 同様な地形条件下での宅地造成の場合の半分程度ら しい.

3 ) 用途別 - 年次別開発面積の中地形別把握 前節で，開発地の用途別およびその立地の中地形 別に標準表層㹂乱深を求めたので，用途別・中地形 別開発面積がわかれば，両者の積として対象地域の 総移動土量が算出できる.

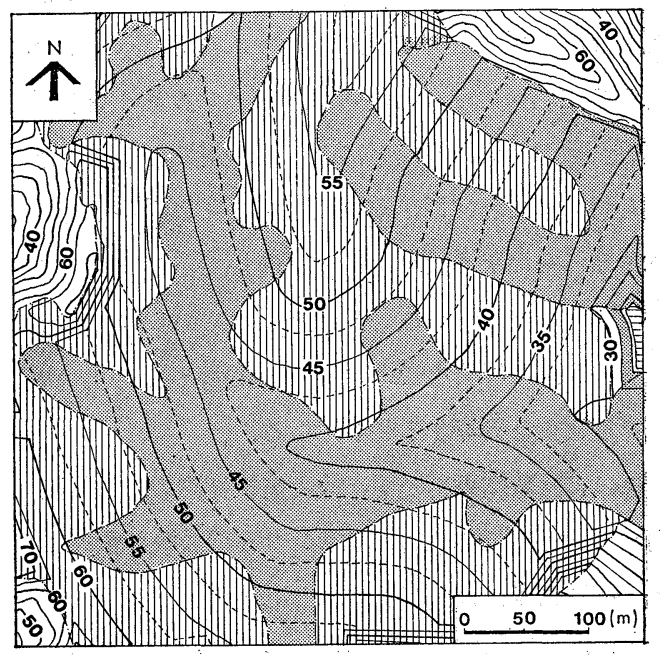

b. 改変後の地形

第 3 図丘陵地における大規模農用地開発による地形改変の例 (知多半島)

Fig. 3 Typical landform modification due to large-scale agricultural development in the hills. An example in the Chita Peninsula, south of Nagoya

See Fig. 1 for legend. 


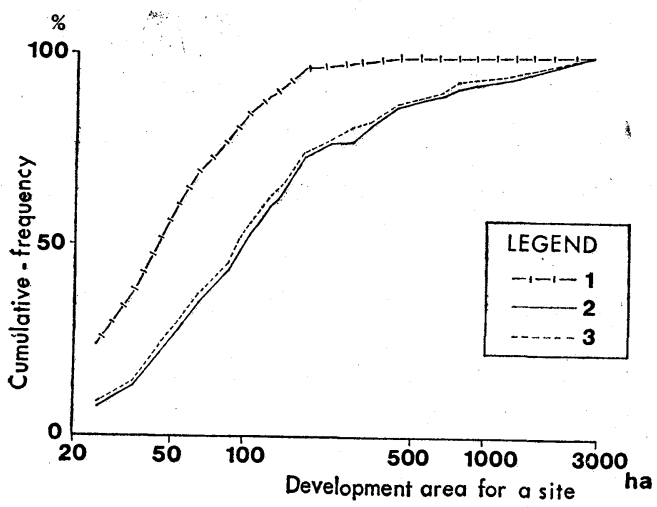

a. 東京 $50 \mathrm{~km}$ 圏 (20 ha 以上)

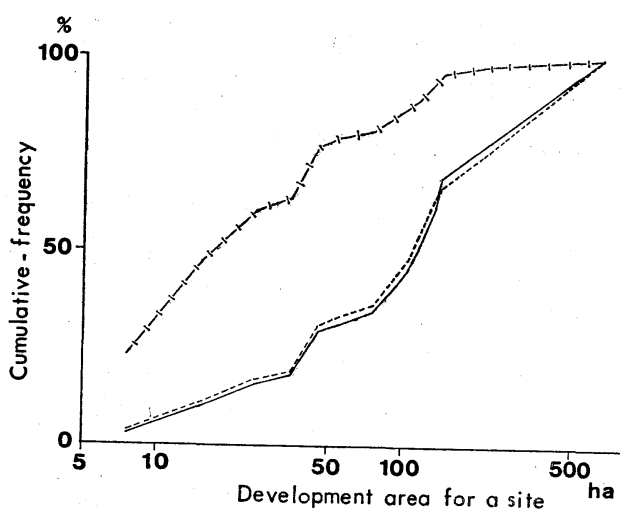

b. 鹿児島 $15 \mathrm{~km}$ 圈 (5 ha 以上)

第 4 図 1 件あたりの開発規模別, 件数・面積・移動土量の累加曲線

1. 件数 2. 面積 3. 移動土量.

Fig. 4 Cumulative frequency curve for number of sites, area and volume of artificially-removed earth according to area of each site in residential developments

$\mathrm{a}$ : in the Tokyo $50 \mathrm{~km}$ sphere $\mathrm{b}$ : in the Kagoshima $15 \mathrm{~km}$ sphere

1. number of sites 2. area 3 . volume of artificially-removed earth.

中地形別開発面積を求めるには，現状では既存の 各種資料を独自の視点で再集計しなければならない， たとえば，住宅用地については，一部の県では開発 年次別の分布図(縮尺 5 万分の 1 程度) と面積などを 記した表とが，対応する形で刊行されているので10)， 既存の土地分類図，土地条件図などを参考に空中写 真判読，地形図読図などによって，適切な中地形分 類を行なっておけば，年次別・中地形別開発面積が 求まる. そのような地図類の完備していない県につ いては, 担当部課作成の表に記されている地名から, 地形図・空中写真上でその位置・範囲を確かめ, 中 地形別面積を概算する必要がある.

次に，全数調查をせずに改変規模変遷の広域的動 向をとらえるのに，適切なサンプルの規模を検討す る. 第 4 図は, 大都市圏の例としての東京 $50 \mathrm{~km}$ 圏 と, 中都市圈の例としての鹿児島 $15 \mathrm{~km}$ 圏 ${ }^{11)}$ で1960 〜 1979 年に開発された，それぞれ 1 件 20 ha 以上お よび 5 ha以上の全住宅用地を対象に， 1 件あたりの 開発面積ごとの開発件数, 面積, および中地形別標 準表層㩇乱深と中地形別開発面積との積として求め
た移動土量の，頻度累加曲線を描いたものである， これから， 1 件 50 ha 以上の住宅用地開発に注目す れば，全体の半分以下の件数で，面積・土量とも全 体の約 $70 \%$ を把握できることがわかる12).そこで， 全国各県について, 1件 50 ha以上の住宅用地開発の 中地形別面積を上記の方法で求めることにした。こ の際, 一部の県については, 国土庁(1975)の「各種 開発事業に関わる土地の自然条件に関する調査」13) を補足的に用いた。

ところで, 大規模用地開発には, 普通数年, とき には 10 年以上を要する.ここでは, 原資料の記載事 項との関連で, 着工年次をもって開発年次を代表さ せる. 数次にわたって工事が進められる，きわめて 大規模な開発事業については, できる限り細かい年 次別の造成(着工) 面積をおさえようとしたが，それ が不可能で，全面積が最初の着工年次に記録されて しまったものもある.なお，大規模住宅用地開発は， 全国的に1960年頃から急に盛んになったことがわか っているので (Tamura, 1976; 田村, 1977)，年次 区分は 1960 年から 5 年ごととし，それ以前は原則と 
して一括した.

農用地開発の場合, 原則として 1 件 $400 \mathrm{ha}$ 以上の 事業は，国または農用地開発公団が行ない，400 ha 未満は都道府県営, さらに $40 \mathrm{ha}$ 未満は市町村営と なっている.このほか私営のものもある.ここでは 一応, 国または公団所管のもの, および北海道営で はあるが 1 件 400 ha以上のものを既存の資料 ${ }^{14)}$ にあ る簡略化された一覧表から抜き出し, 開発年次・面 積などを転記した，同時に各事業区域の位置を 5 万 分の 1 地形図と対照して確認し, 一方で地形分類を 行なって, 中地形別面積比を概測した，その比と表 示された面積から各区域の中地形別面積を求め, そ れを集計した，その際，有意な地形改変を伴わない 単なる戋場整備のようなものを除外したことはいう までもない。ここで抽出された 2 百数十地区につい て，担当の各事業所にさらに詳しい資料の提供を依 頼し, 利用できた一部の資料に基づいて中地形別面 積や移動土量推定の妥当性を検討した. 年次別集計 にあたっては, 住宅用地の場合と同様, 着工年次に 注目した。 また，大型建設機械を駆使した大規模農 用地開発は, 1962 年開始の国営開拓パイロット事 業 ${ }^{15)}$ ともに始まったとみてよいので，その年を起 点に 5 年ごとに年次区分した.

このほか工業用地, およびレクリエーション用地 のうちとくに広い面積を占めるゴルフ場についても， 年次別・中地形別開発面積の把握に努めたが, 住宅 用地・農用地の場合と比べて良質の原資料の集積が まだ必ずしも十分とはいえない16).

\section{III 中地形別開発面積からみた大規模} 改変の動向地形

\section{1）全国的動向}

上述した視点・方法により, 各種資料を整理・集 計した結果は，すべて開発目的ごとの総面積および 中地形別面積比の年次変化という形で提示するが, その前に，それと同じ中地形スケールで国土の状況
を概観する(第 5 図)．周知のように，日本の国土の 約 $2 / 3$ は山地で, それに丘陵地をあわせると全体の 約 $3 / 4$ になる. 一方, 宅地・農地など強度に利用さ れた土地は，残り約 $1 / 4$ の低地・台地に集中してい る. 大規模土地改変が盛んになって間もない1967年 の時点では, 全国の宅地(工業用地を含み, 国土の約 $1 / 40$ )の約 $2 / 3$ が低地に, 約 $7 / 8$ が低地と台地に集中 していた．斎藤(1965)は，1960年国勢調査の人口集 中地区(DID) を市街地 (built-up area) とみなし, その面積 (国土の約 1\%)の $92 \%{ }^{17}$ )が低地・台地にあ ったと報告している．農用地(国土の約 $1 / 17$ )の場合， 低地への集中傾向は宅地より弱いものの, その半分 強が低地・台地にあった. なお当時は, 農用地の面 積が宅地の 6 倍近くあった.

これに対して，1960年頃から急に盛んになり，70 年代初頭に最盛期を迎えた大規模住宅用地開発は, 丘陵地を利用する割合がきわめて高いことで特徴づ けられる(第 6 図).1950年代の大規模住宅用地開発 は，その大半が台地を利用して行なわれていた。 こ のこと自体, 第 5 図に示す従来の宅地の立地傾向と 多少異なるものであるが， 60 年代に入って，大規模 宅地開発の面積が激増するともに, 開発の重点は丘 陵地に移るようになり，さらに，60年代後半には， 台地よりも，丘陵地を利用する開発が多くなった。 これは，第立章-2)に示した台地と丘陵地とでの住 宅地開発に伴う地形改変規模・様式の著しい相違を 考えれば，きわめて重要な変化といえる18)．すな わち，1960年という時点は，日本の都市の立地傾向 の転換期として重要な意味をもつ(Tamura, 1976 ; 田村，1977).この新しい傾向は，70 年代中期に開 発総面積が減少に転じた後も継続している.

山地に造成される住宅用地は, 総面積では1960年 代後半から, 中地形別面積比では70年代初頭に, そ れぞれ急増し，いずれも70年代後半に急減した．実 際には，70年代前半に着工されて同年代後半も工事 継続中のものがかなりあったとみられる. 低地での 


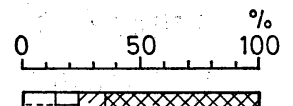

1

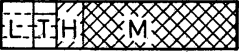

2

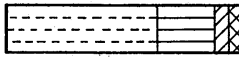

3

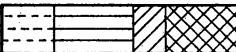

Total area

37

0.9

5.3

第 5 図国土全域および1967年当時の宅地・農用地の総面積と中地形別面積比

1. 国土全域 2. 宅地 3. 農用地.

$\mathrm{L}:$ 低地 $\mathrm{T}:$ 台地 $\mathrm{H}$ : 丘陵地 $\mathrm{M}$ : 山地.

第 6 図 第11図も同様.

Fig. 5 Areal proportion of the intermediate-scale geomorphic units for the whole national land and for some land-use of Japan in 1967

1. the whole national land 2 . building sites including both residential and industrial sites 3 . agricultural lands.

$\mathrm{L}$ : lowlands (Holocene alluvial and coastal plains) $\mathrm{T}$ : terraces (mostly late-Pleistocene river and coastal terraces) $\mathrm{H}:$ hills (mostly composed of early-Pleistocene and Neogene deposits) M:mountains.

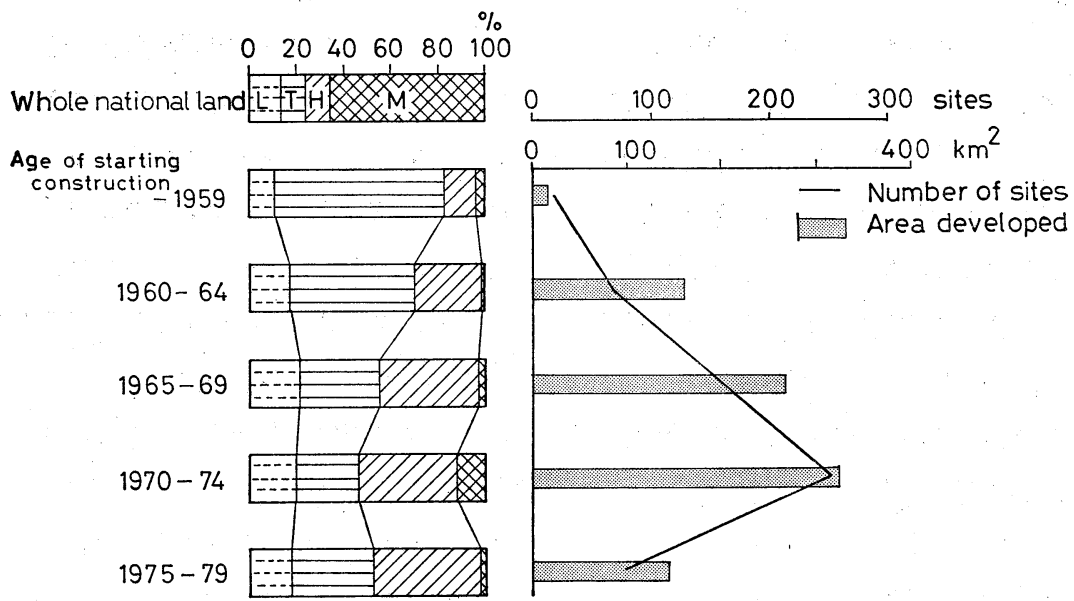

第 6 図国土全域における大規 模 住宅用地開発(1 件 50 ha 以上)の件数，総 面積と中地形別面積比の推移

Fig. 6 Changes in areal proportion of the intermediate-scale geomorphic units in large-scale residential development sites ( $>50$ ha in a site) in Japan

See Fig. 5 for legend.

大規模住宅用地開発は, 総面積では全般的傾向と同 様に60年代に急増し，70年代前半に極大に達した後， 減少に転じるが, 中地形別面積比では 60 年以後, 20 \%を若干下回るあたりでほぼ一定している.

大規模農用地開発面積(第 7 図) 女，住宅用地の場 合と同様，1960年代から急増傾向にあったが，70年 代前半をピークに著しい減少に転じた．当初から台
地を利用する割合が高かったが，最近では山地の利 用が増大している。低地・水面を利用する割合は一. 貫して減少傾向にあり，とくに大規模干拓 ${ }^{19}$ (は1977 年以後まったく計画・着工されていない.

ところで, 大規模農用地開発の総面積に占める北 海道の割合は，最盛時で $90 \%$ 近く，1970年代末でも $50 \%$ 程度である. 原資料をみると, 北海道ではとく 
A. Whole national land

$\%$
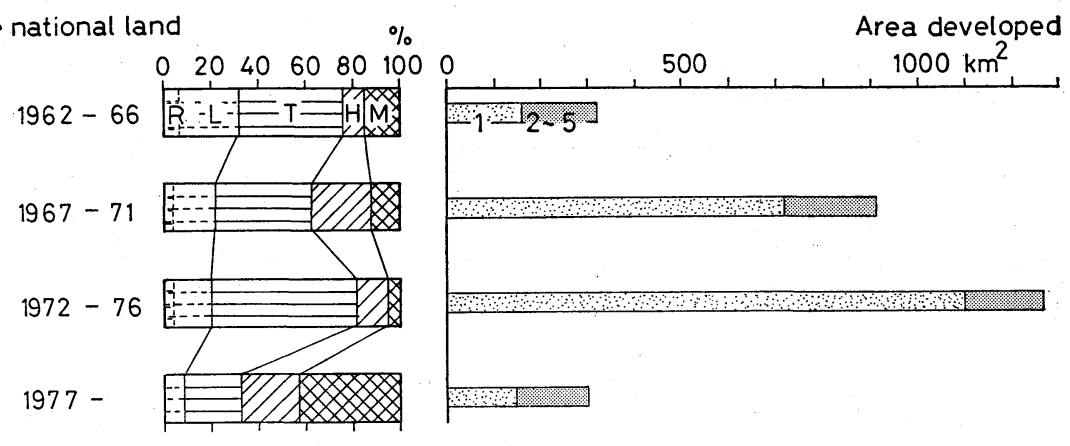

B. Except Hokkaido

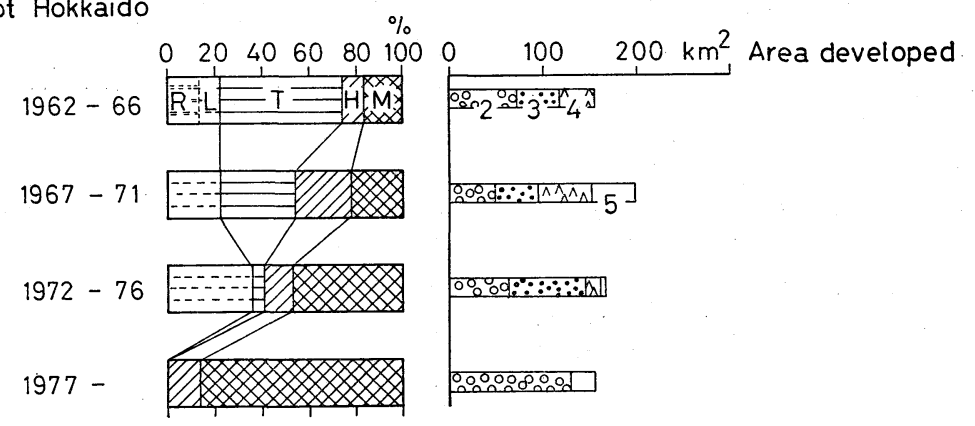

第 7 図 国土全域 (A) および北海道を除く地域 (B)における大規模農用地開発 (1 件 $400 \mathrm{ha}$ 以上) の総面積と中地形別面積比の推移

1. 北海道 2. 東北 3 . 九州 4 . 関東 5 . その他.

$\mathrm{R}$ : 低地のうちの干拓地.

Fig. 7 Changes in areal proportion of the intermediate-scale geomorphic units in large-scale agricultural development sites ( $>400$ ha in a site) in Japan 1. Hokkaido 2. Tohoku 3. Kyushu 4. Kanto 5. other districts. R: Reclaimed land (included in "lowlands" in other Figures). See Fig. 5 for other legend.

に台地・低地での造成が盛んである．これを除外す ると，すなわち北海道以外の地域では，山地に農用 地を造成する割合が，時期を追って急速に高まって いることが，第 7図-(B)によく示されている.70 年代に入ってからの山地での大規模農用地開発は, 主として東北地方で進行しているが，これを原資料 で詳しくみると，北上・阿武郎山地の山頂緩斜面の 広い地域で草地造成が活発化したことがわかる.

なお，1960７0 年代に全国で開発された 1 件 400 ha 以上の大規模農用地の総面積は約 $2,800 \mathrm{~km}^{2}$ で, 同期間中の 1 件 $50 \mathrm{ha}$ 以上の大規模住宅用地開発の 総面積約 $950 \mathrm{~km}^{2}$ のほぼ 3 倍である. なお，それぞ れ 1 件 400 ha以下, および 50 ha以下の, より小規
模なものまで含めた開発面積を, 毎年の『国土利用 白書』の記載から推定すると，1970 1979年の合計 で，農用地は住宅用地を約 $25 \%$ 上回る.

工業用地開発は, 『工業統計表』記載の取得面積 でみると，たとえば 1970 1974 年には約 $240 \mathrm{~km}^{2}$, 1975 1979年には約 $90 \mathrm{~km}^{2}$ と, 同期間の 1 件 $50 \mathrm{ha}$ 以上の住宅用地開発総面積の $3 / 4 \sim 2 / 3$ 程度であるが， 実際に造成された面積は，さらにその半分以下とみ られる. 上記の『国土利用白書』の記載から，規模 を問わずに比較すれば，1970 1979 年で約 $700 \mathrm{~km}^{2}$ の工業用地が造成されたと見積られ，これは，住宅 用地開発総面積の約 $1 / 3$ 程度である. 中地形別には, 低地と埋立地をあわせて全体の半分近くに達する点 


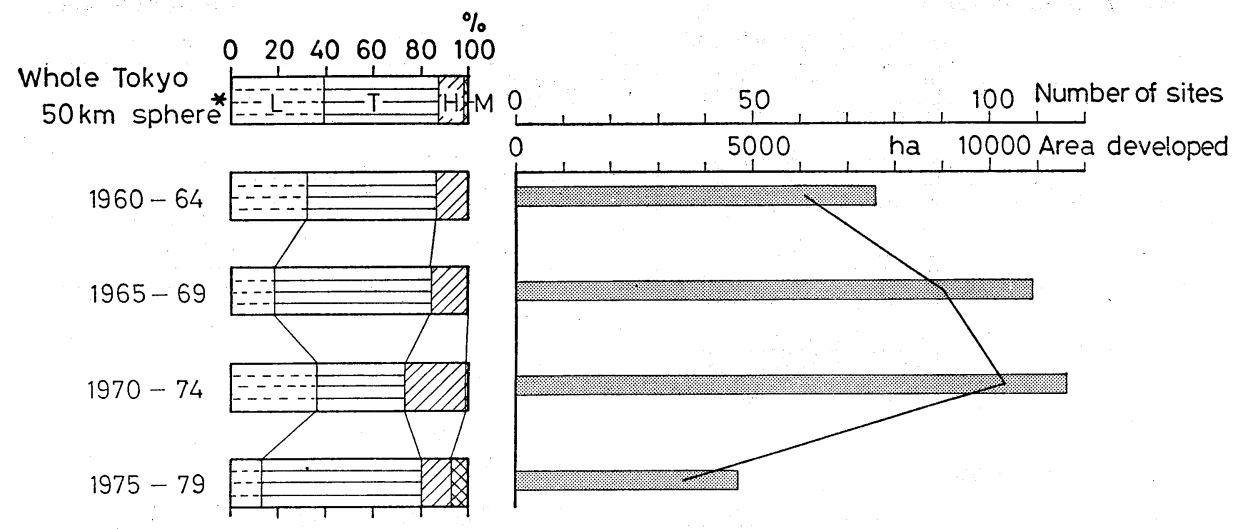

第 8 図東京 $50 \mathrm{~km}$ 圈における住宅用地開発の件数, 総面積と中地形別面積比の推移 ( 1 件 50 ha 以上)

* 湖・海面を含まない陸域全域. 第 9 図〜第10図も同様.

Fig. 8 Changes in areal proportion of the intermediate-scale geomorphic units in large-scale residential development sites ( $>50$ ha in a site) in the Tokyo $50 \mathrm{~km}$ sphere

* Including previously developed, newly developed, and undeveloped areas. See Fig. 5 for legend.

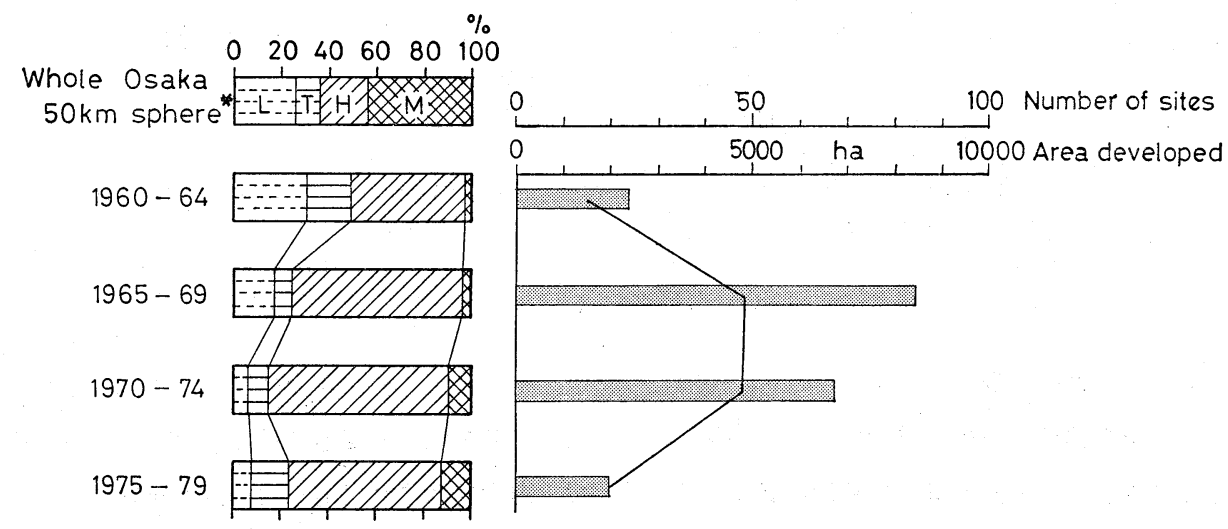

第 9 図大阪 $50 \mathrm{~km}$ 圈における住宅用地開発の件数, 総面積と中地形別面積比の推移 ( 1 件 50 ha 以上)

Fig. 9 Changes in areal proportion of the intermediate-scale geomorphic units in large-scale residential development sites ( $>50$ ha in a site) in the Osaka $50 \mathrm{~km}$ sphere

See Figs. 5 and 8 for legend.

が，住宅用地や農用地の開発と大きく異なる。しか

し，大規模開発が一般化する以前に比べれば，丘陵 地を利用する割合が高まってきたようである。

ゴルフ場開発も，1950年代末から60年代に急增す

る. 60 年代以後の開発総面積は約 $1,300 \mathrm{~km}^{2}$ で, 1
件 50 ha 以上の住宅用地のそれの 1.4 倍に達する. また，中地形別には約 $60 \%$ が丘陵地に立地する ${ }^{20)}$.
2). いくつかの都市圈における住宅用地開発 に伴う大規模地形改变状況の比較

1)でみた全国的動向は，いうまでもなく地域によ 


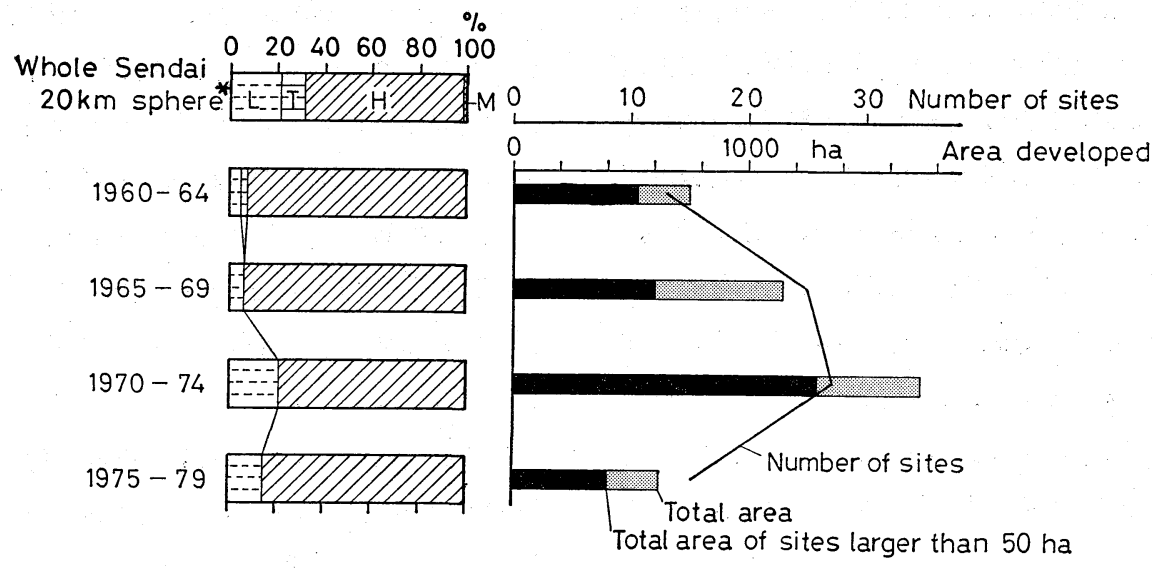

第 10 図 仙台 $20 \mathrm{~km}$ 圈におお拄宅用地開発の件数, 総面積と中地形別面積比の推移 ( 1 件 10 ha 以上)

Fig. 10 Changes in areal proportion of the intermediate-scale geomorphic units in large-scale residential development sites ( $>10$ ha in a site) in the Sendai $20 \mathrm{~km}$ sphere

See Figs. 5 and 8 for legend.

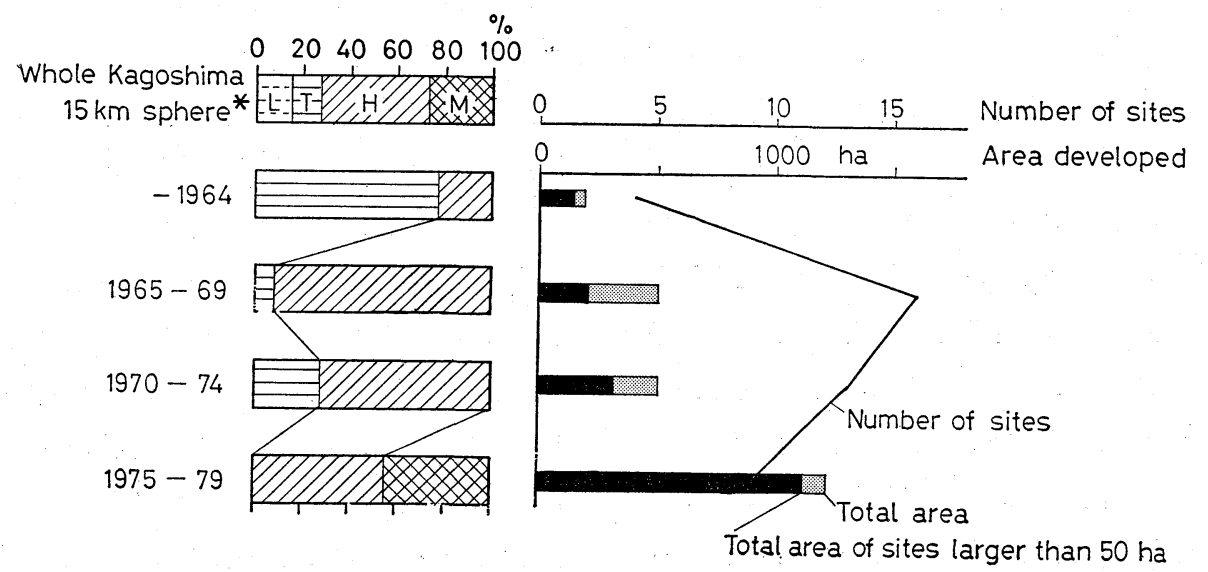

第 11 図鹿児島 $15 \mathrm{~km}$ 圈における住宅用地開発の件数, 総面積と中地形別面積比の推移 ( 1 件 5 ha 以上)

Fig. 11 Changes in areal proportion of the intermediate-scale geomorphic units in large-scale residential development sites $(>5$ ha in a site) in the Kagoshima $15 \mathrm{~km}$ sphere

See Figs. 5 and 8 for legend.

って少しずつ異なった現われ方をする.ここでは,

質的・量的に資料集積状況のよい住宅用地開発につ

いて，いくつかの大・中都市圏の比較を試みる.

住宅用地開発を要因とする人工地形現象をみる際

の都市圈は,たとえば河成地形の形成を論じる際の
流域になぞらえられる, 地形学的に有意な空間的単 位とみなせる。対象として選んだのは, 東京, 大阪, 名古屋 (図省略)の 3 大都市圈と, 中都市圈のうち, 大きなものから仙台，同じくあまり大きくないもの から鹿児島の各都市圏である(第 8 図〜第11図). 
これらの都市圈には, 山地を除く 3 種の中地形が いずれもある程度含まれ，しかもその構成比が異な る. 各都市圈の範囲は，実際の宅地開発の分布状況 をみて, 行政界に関係なく中心駅からの等距離圈 （東京・大阪は $50 \mathrm{~km}$, 名古屋 $30 \mathrm{~km}$, 仙台 $20 \mathrm{~km}$, 鹿児島 $15 \mathrm{~km})$ として設定したが，これらの範囲は 1975年国勢調查の通勤・通学圈に照らしても，ほぼ 妥当なものと思われる. 各都市圈内全域の中地形別 面積比（第 6 図, 第 7 図に対する第 5 図最上行のグ ラフに相当するもの）を，それぞれの図の冒頭に掲 げておく

図示した各都市圈において共通に, 圈内全域の中 地形別面積比に比べて，新たな住宅用地開発の際に， 丘陵地を利用する割合が高いことが注目される。し かもこの割合が，当初から高い仙台 $20 \mathrm{~km}$ 圈を除き， 1960年代末ないし70年代前半まで, 年次を追って増 大する傾向が明瞭である. しかし，その程度は都市 圈によって異なり, それは各都市圈の地形構成に関 連している。

たとえば，元来，台地の面積比の大きい東京 50 $\mathrm{km}$ 圈では，依然として台地を利用する割合が最も 高く，低地・埋立地を利用する割合も $20 \%$ 近くを保 っている(第 8 図)．これに対して，同じ大都市圈で も山地・丘陵地の面積比が $50 \%$ を上回る大阪 $50 \mathrm{~km}$ 圈では，1960年代初頭から丘陵地を開発対象にする 割合が高く，60年代後半以後，それが $70 \%$ を上回っ ている.また，ここでは低山地に大規模住宅用地を 開発する例が 60 年代初めからあり，70年代に入ると その割合が $10 \%$ 近くに達するようになった（第 9

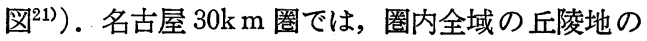
面積比は $20 \%$ 弱であるが， 60 年代後半 ${ }^{22)}$ から 70 年代 前半にかけて, 大規模住宅用地開発に丘陵地を利用 する割合が $80 \%$ を上回った．ここでは，70年代後半 に至って台地・低地を利用する割合が急增するとい う，他地域にない特色がみられる。

総面積の $70 \%$ を丘陵地が占める仙台 $20 \mathrm{~km}$ 圈では,
1950年代末から丘陵地を利用した大規模住宅用地開 発が行なわれている．60年代以後も，1件 $50 \mathrm{ha}$ 以 上の開発をとれば，ほぼ $100 \% ， 10$ ha以上でも常に $80 \%$ 以が，丘陵地に立地している(第10図).この 結果, この圈内の DID の中地形別面積比は, 1960 年には台地が約 $50 \%$ ，丘陵地が約 $10 \%$ であったのに 対して，75年には丘陵地が約 $40 \%$ を占めるに至っ た(田村ほか，1978)。

鹿児島 $15 \mathrm{~km}$ 圈でも，圈内全域の面積の $50 \%$ 弱の 面積比を占める丘陵地に, 1 件 5 ha以上の住宅用地 開発の70\%以上が集中している(第11図)。ただし， ここで丘陵地としたのは，比高の大きな火砕流台地 の前縁で開析が進み，原面がほとんど消失した部分 であり, この点, 他地域の丘陵地とその内容を若干 異にする. 鹿児島圈で上記の規模の住宅用地開発が 盛んになったのはここに例示した他の都市圈より やや遅れて1960年代後半である. 1970年代に入って も開発総面積が減少せず，同年代後半には逆にそれ 以前の 2 倍以上に増大している点も，他の都市圈で はみられない特色である(第11図)。

住宅用地開発総面積が1960年以後急増し，70年代 初頭に極大を迎えた後に急減するという,第而章-1) で指摘した全国的傾向（第 6 図)は，仙台圈では明瞭 に現われている. 東京圈では，60年代後半にすでに かなり大量の大規模住宅用地開発がみられ，70年代 前半のピークは鈍い，大阪圈では，むしろ60年代後 半の方が70年代前半より大規模住宅用地開発面積が やや大きい(件数は両時期でほほ同じ)，大規模住宅 用地開発の活発化がやや遅れた名古屋圈 ${ }^{22)}$ では, 70 年代後半の減少がそれほど著しくない，同じく開始 の遅い鹿児島圈でも, 上述のように, 開発総面積は 70年代後半にむしろ増大している.このように，大 規模住宅用地開発総面積の増減は，中心都市の規模 やその拡大開始時期によって，その位相が少しずっ ずれるようである. 


\section{IV 移動土量の推算とその比較}

第而章に整理して示した，各種用地開発における 地形利用傾向の変化は, 第目章に述べた手順で, 地 形改変規模・様式の変化に読みかえられる.

東京 $50 \mathrm{~km}$ 圈を例にとると，1960年から1979年ま での 20 年間に, 1 件 $50 \mathrm{ha}$ 以上の住宅用地開発に伴 って発生した移動土量は, 埋立地, 低地, 台地, 丘 陵地, 低山地または大起伏丘陵地で, それぞれ 1.5 $\times 10^{8} \mathrm{~m}^{3}, 0.6 \times 10^{8} \mathrm{~m}^{3}, 3.5 \times 10^{8} \mathrm{~m}^{3}, 2.6 \times 10^{8} \mathrm{~m}^{3}$ およ び $0.2 \times 10^{8} \mathrm{~m}^{3}$ で，あわせて約 $8.4 \times 10^{8} \mathrm{~m}^{3}$ であるこ とが,第 8 図に示した中地形別開発面積と第立章-2) で推定した標準表層摫乱深から算定される.すなわ ち, 台地・丘陵地での改変量が圧倒的に大きい. たこれは, 非改変地を含む東京 $50 \mathrm{~km}$ 圈全域で, 約 $6.4 \times 10^{3} \mathrm{~m}^{3} / \mathrm{km}^{2} \cdot \mathrm{y}$ の割合で, 土が直接人工的に動 かされたことに相当する．この量を「広域土量移動 速度」と称する．その值を年代別にみると，1960年 以前が $7.2 \times 10^{2} \mathrm{~m}^{3} / \mathrm{km}^{2} \cdot \mathrm{y}$ であるのに対し，1960年 代には $6.8 \times 10^{3} \mathrm{~m}^{3} / \mathrm{km}^{2} \cdot \mathrm{y}$ と激增し,さらに 70 年 代前半には $8.5 \times 10^{3} \mathrm{~m}^{3} / \mathrm{km}^{2} \cdot \mathrm{y}$ になる. 70 年代後 半には, 改変面積の激減に伴い広域土量移動速度は $3.4 \times 10^{3} \mathrm{~m}^{3} / \mathrm{km}^{2} \cdot \mathrm{y}$ と減少するものの, 依然として 大きな值を示している.

第 4 図に示した改变面積別移動土量頻度分布を考 虑すると，小規模開発まで含めれば，上記の各值の 約 1.5 倍の移動土量拉よび広域土量移動速度が想定 される. 1 件 20 ha 以上の住宅用地開発に工業用地, ゴルフ場などの開発による分をあわせれば，1961〜 1979 年の総移動土量は約 $1.4 \times 10^{9} \mathrm{~m}^{3}$ ，この 20 年間の 広域土量移動速度は $1.1 \times 10^{4} \mathrm{~m}^{3} / \mathrm{km}^{2} \cdot \mathrm{y}$ と推測され る.これらを, 門村・山本(1978)が整理した，湿潤 温帯丘陵地の自然林下での平均削剝速度 $10 \sim 50 \mathrm{~m}^{3}$ $/ \mathrm{km}^{2} \cdot \mathrm{y}$ と, 移動距離の違いを無視して比較すると, 1960年以前の住宅用地開発によるものだけで十数倍 〜数十倍, 同じく1970年代前半の大規模住宅用地開
発によるものでは百数十倍 数百倍に, それぞれ相 当する ${ }^{23)}$.

同様の操作を，各地域について行なうことができ る. そのうち, 住宅用地の年平均開発面積, および それによる広域土量移動速度を比較したものが，第 12図である. いくつかの都市圈 (第而章-2)) につい ては，その数值を第 1 表に示す. 第12図では集計の 単位として, 都市圈を用いた所と, 利用できた資料 の関係で市域を用いた所がある。また集計対象とし た 1 件当たりの最小開発面積は, 東京・名古屋・大 阪各都市圈では $50 \mathrm{ha}$, 他の都市圈と市域では $5 \mathrm{ha}$ である.したがって，大都市圈では相対的に小さめ の，また市域単位で示した中都市では相対的に大き めの数值が，それぞれ表現されているとみられる. さらに，統計期間も，全国的に開発が最も盛んであ った1970年代前半を含む点は共通しているものの， 地域により少しずつ異なる. しかし，大局的傾向の 比較は可能であろう.

第12図，第 1 表からこれらの都市圈・市域にお いて, 開発総面積は中心都市の規模にほぼ対応し, 広域土量移動速度は $10^{3} \sim 10^{4} \mathrm{~m}^{3} / \mathrm{km}^{2} \cdot \mathrm{y}$ であること がわかる.ところで, この広域土量移動速度は地域 間で数倍の開きがありこれは抢もにその域内にお ける中地形の面積比に関係すると考えられる．すな わち, 丘陵地の面積比が高い仙台(第10図), 風化花 崗岩からなる開析ペディメント状の地形を住宅用地 開発の主な対象にしている広島(赤木，1980)，70年 代後半に山地の改変が進んだ鹿児島, 切土が一種の 土堙改良材に利用されるため，切土地のみからなる という特異な造成が行なわれている那覇 (Takeuchi et al., 1981)では, 広域土量移動速度が大きくなっ ている，しかし，細かくみると，広域土量移動速度 は，開発面積の大きさによっても少しずつ異なる。 大阪 $50 \mathrm{~km}$ 圈では，丘陵地開発が大きな割合を占め るが，開発面積が東京 $50 \mathrm{~km}$ 圈と比べ小さいので, 広域土量移動速度は，台地開発の割合の大きい東京 


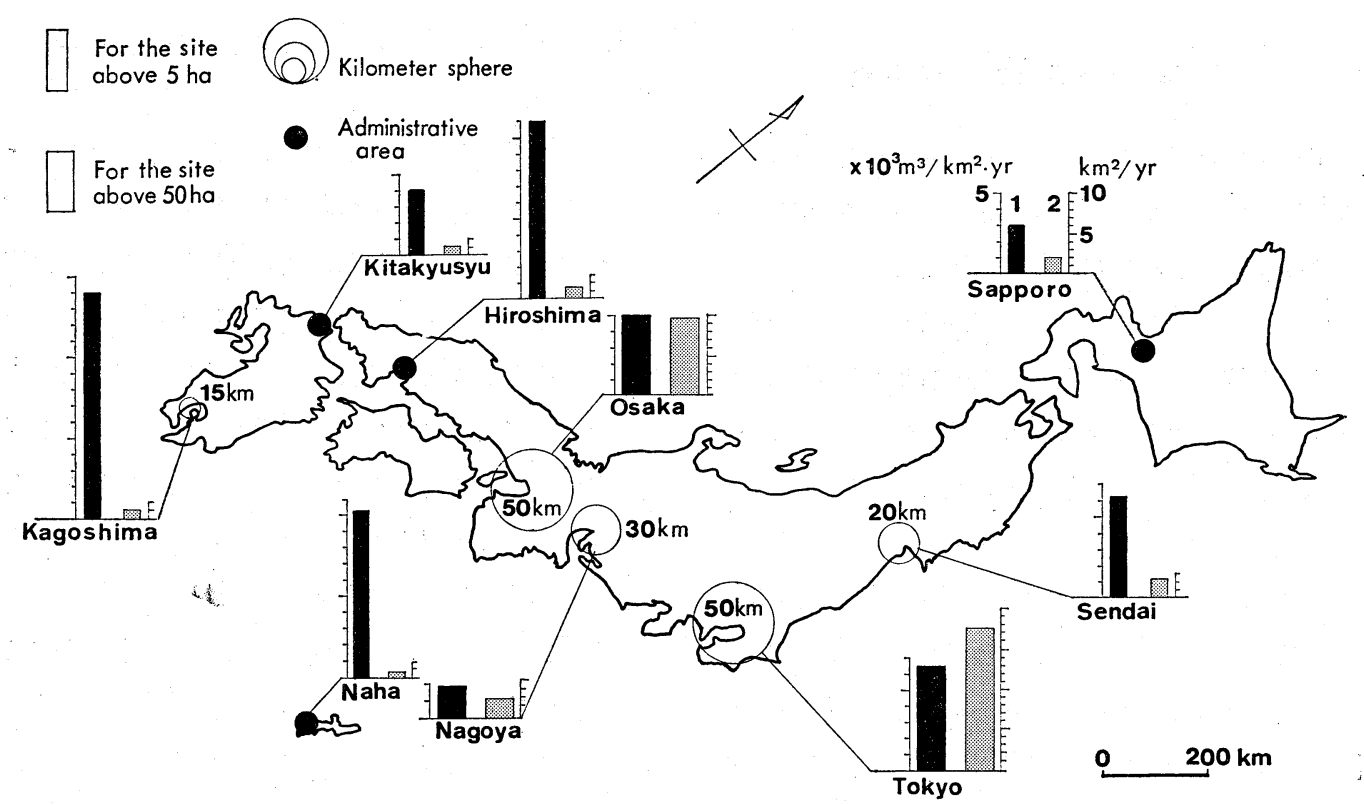

第 12 図宅地開発に伴う対象地域内での広域土量移動速度と年平均開発面積の 地域間比較

1. 広域土量移動速度 2. 年平均開発面積.

Fig. 12 Inter-regional comparison of artificially-removed earth volume and its rate

1. annual regional rate of removal artificial of earth due to residential developments 2 . annual rate of residential develop. ments by area.

第 1 表 各都市圈における住宅用地開発とそれに伴う移動土量

Table 1 Residential developments and artificially-removed earth volume within the several metropolitan areas

\begin{tabular}{|c|c|c|c|c|c|}
\hline \multirow[t]{2}{*}{$\begin{array}{c}\text { Metropolitan area } \\
\text { (measurement period) }\end{array}$} & \multicolumn{2}{|c|}{$\begin{array}{l}\text { Total development } \\
\text { area(minimum } \\
\text { of one site) }\end{array}$} & \multirow{2}{*}{$\begin{array}{c}\begin{array}{c}\text { Total volume of } \\
\text { artificially-removed } \\
\text { earth }\end{array} \\
\times \times 10^{7} \mathrm{~m}^{3}\end{array}$} & \multirow{2}{*}{ 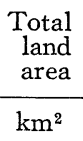 } & \multirow{2}{*}{$\begin{array}{l}\begin{array}{l}\text { Annual regional } \\
\text { rate of artificial } \\
\text { removal of earth }\end{array} \\
\times \times 10^{3} \mathrm{~m}^{3} / \mathrm{km}^{2} \cdot \mathrm{yr}\end{array}$} \\
\hline & $\times 10 \mathrm{~km}^{2}$ & (ha) & & & \\
\hline $\begin{array}{c}\text { Tokyo } 50 \mathrm{~km} \text { sphere } \\
(1960 \sim 1979)\end{array}$ & 34.8 & $(50)$ & 83.6 & 6,550 & 6.4 \\
\hline $\begin{array}{c}\text { Osaka } 50 \mathrm{~km} \text { sphere } \\
(1960 \sim 1979)\end{array}$ & 19.6 & $(50)$ & 71.0 & 7,030 & 5.0 \\
\hline $\begin{array}{c}\text { Nagoya } 30 \mathrm{~km} \text { sphere } \\
(1965 \sim 1979)\end{array}$ & 3.5 & $(50)$ & 7.6 & 2,510 & 2.0 \\
\hline $\begin{array}{l}\text { Sendai } 20 \mathrm{~km} \text { sphere } \\
\qquad(1960 \sim 1979)\end{array}$ & 4.4 & ( 5$)$ & 15.6 & 1,210 & 6.4 \\
\hline $\begin{array}{l}\text { Kagoshima } 15 \mathrm{~km} \text { sphere } \\
\quad(1960 \sim 1979)\end{array}$ & 2.4 & ( 5$)$ & 11.4 & 410 & 14.0 \\
\hline
\end{tabular}

圈とほほ同じ值になる．また，名古屋 $30 \mathrm{~km}$ 圈では， 1 件 50 ha 以上の開発地の総面積が小さく ${ }^{24)}$, しか もそれが台地・低地にも比較的高い割合で分布する ため，広域土量移動速度が小さくなっている、いず
れにしても, 広域土量移動速度は, 上述の湿潤温帯 丘陵地の自然状態での平均的削剝速度の数十倍 数 百倍であることには変わりない。

全国的には，第II 章-2）で推定した中地形別標準: 
表層攪乱深と第 6 図から，1 件 50 ha 以上の大規模 住宅用地開発による総移動土量は, 第 I章-3) で述 べた方法により，1960 1979年の 20 年間で約 $3 \times 10^{9}$ $\mathrm{m}^{3}$ となる. 中地形別にみれば, 総移動土量の約半分 が丘陵地での開発に伴うものであり, 年代別にみれ ば, 20 年間の総移動土量の約 $1 / 3 か ゙ 1970 \sim 1974$ 年に生 ビたものである.なお， 1 件 50 ha 未満の小規模開 発によるものを含めても, 総移動土量は上記の值の 1.5倍程度であることが, 第 4 図などから推測される. 農用地開発については, 第而章-1）に述べた開発 総面積やその中地形別面積比と, 第II 章-2）に例示 した中地形別標準表層攂乱深が，住宅用地開発より やや小さい傾向を示すことを考えあわせると，全国 的にみて住宅用地開発によるものと同程度の総移動 土量が推定される. 工業用地開発についても, 精度 は低下するものの，同様にして住宅用地開発による ものの $1 / 3$ 程度の総移動土量が推算される.これは, 工業用地と住宅用地との開発面積の比にほぼ等しい が, 工業用地開発の場合, 総移動土量の $1 / 3$ 程度が 埋立地造成によるものである点が大きく異なる。 ま た, ゴルフ場開発に伴う総移動土量は, 大規模住宅 用地開発によるものとほぼ同程度と推測される.

これらをあわせると，1960年からの 20 年間に全国 で住宅用地, 工業用地, 農用地, ゴルフ場用地の開 発に伴って生じ総移動土量は, $10^{10} \mathrm{~m}^{3}$ のオーダー に達する。これから同期間の全国平均の広域土量移 動速度を求めると, (1 2) $\times 10^{3} \mathrm{~m}^{3} / \mathrm{km}^{2} \cdot \mathrm{y}$ となり ${ }^{25)}$, これは東京 $50 \mathrm{~km}$ 圈の同種の值の数分の $1 \sim 1 / 10$ で あるが，それでも湿潤温帯丘陵地の自然状態での平 均削剝速度の数十倍〜百数十倍である.これには道 路・鉄道などの建設に伴う移動土量は含まれていな い.

さらに，全国的規模での地形改変に伴う移動土量 を考えようとする場合, 鉱産資源の採取による改変 は無視できない，そのうち，骨材用土石採取による 総移動土量は, 1950 年代後半からの 20 年間で約 $3 \times$
$10^{9} \mathrm{~m}^{3}, 1980$ 年には $3.7 \times 10^{8} \mathrm{~m}^{3}$ と見積もられている (Kadomura, 1980)。これを広域土量移動速度に換 算すれば, 前者からは $4 \times 10^{2} \mathrm{~m}^{3} / \mathrm{km}^{2} \cdot \mathrm{y}$, 後者から は $1 \times 10^{3} \mathrm{~m}^{3} / \mathrm{km}^{2} \cdot \mathrm{y}$ 程度の值が求まる。

上記の各種開発に伴う移動土量の間には，ある程 度の重複が含まれていること汭を考慮すると，各種 開発行為による全国土を対象とした広域土量移動速 度は, 最近約 20 年間の平均で $(3 \sim 4) \times 10^{3} \mathrm{~m}^{3} / \mathrm{km}^{2} \cdot \mathrm{y}$ 程度とみてよいのではなかろうか.

\section{V まとめと今後の課題}

現代日本における人工地形学の最大の研究対象と 考えられる，大規模土地改変現象を的確に把握する 第一歩として, 直接的な地形改変の規模・様式を知 ろうとした。 それを端的に示す統計資料が整備され ていない現状では, 各種用地開発の中地形別面積が よい鍵となる.たとえば，各種開発行為において， 開発地の用途および開発に利用される中地形の違い は, 改変様式や単位面積当たりの改変強度などの違 いをよく反映する. そこで，用途別・中地形別の標 準表層粯乱深を，代表的な改変地についての大縮尺 図を含む開発計画書などから求め, 一方, 各種開発 地の位置や面積などを示す散在した資料を収集して， それに地形分類や図上計測などの操作を加えること によって中地形別開発面積を求めれば，両者の積か ら開発に伴う移動土量を推算し, 改変規模の簡便な 指標とすることができる.このような操作を経て, 下記の事実が明らかになった。

1. 各種用地の開発は, 国内各地で1960年頃から 急に盛んになり，1970年代初頭にピークを迎えた後， 減少傾向にある. 用途別開発面積は, 農用地, 次い でゴルフ場が大きく，以下，住宅用地，工業用地と 続く. 1960 1979年の 20 年間に, 全国で開発された 1 件 50 ha 以上の大規模住宅用地の総面積は, 約 $950 \mathrm{~km}^{2}$ に達する.

2. 1960 年頃の開発面積の急増と同時に, 各種用 
地が丘陵地に(さらに一部は山地にも)立地する傾向 が急に強くなった。たとえば， 1 件 50 ha 以上の大 規模住宅用地開発の総面積に占める丘陵地の割合は, 60 年代後半以後は $40 \%$ 台を保っている. これは, 従 来の低地(および台地)に依存する伝統的な地形利用 パターンを大きく変えるものであると同時に, 開発 に伴う移動土量の增加を著しく大きくすることにも なった. 1960年という時点は, 日本における地形利 用や地形改変の歴史の上で, 最大の転換期のひとつ と考えられる。

3. 1 件 50 ha 以上の大規模住宅用地開発に伴う 移動土量は, 1960 年以後の 20 年間に全国で約 $3 \times 10^{9}$ $\mathrm{m}^{3}$ に達する. その約 $1 / 3$ が 1970 1974年に記録され た. 中地形別にみると, 総移動土量の約半分が丘陵 地で生じたものである.より小規模な開発まで含め ると, 総移動土量は, 上記の 1.5 倍程度になると見 積もられる. これに, 同様に推定した農用地, 工業 用地, ゴルフ場用地などの開発に伴う移動土量をあ わせると, 1960 年からの 20 年間で約 $1 \times 10^{10} \mathrm{~m}^{3}$ に達 するものと思われる. いくつもの中地形単位にまた がる広い地域で, 地形改変により生じた年間総移動 土量を, 非改変地を含むその地域全体の面積で除し た量を,「広域土量移動速度」と呼ぶ. 上記の值か ら求めた全国の 20 年間における広域土量移動速度 は, $(1 \sim 2) \times 10^{3} \mathrm{~m}^{3} / \mathrm{km}^{2} \cdot \mathrm{y}$ になる. この值は, 湿潤 温帯丘陵地の自然条件での平均的削剝速度の数十倍 ～百数十倍に相当する.

4. 東京 $50 \mathrm{~km}$ 圈について, 1960 1979年の住宅 用地, 工業用地, ゴルフ場の開発に伴う広域土量移 動速度を推算すると, 上記の全国平均の数倍〜 10倍 の值になる. 同じ東京圈において, 1 件 $20 \mathrm{ha}$ 以上 の住宅用地開発に伴う広域土量移動速度の年代によ る変化をみると, 1960年を境に 20 倍近くに急増して いることがわかる. この值は, 1970年代中期以後, 開発面積の減少に伴い低下するが, 依然高い水準に ある. 中地形別には, 東京 $50 \mathrm{~km}$ 圈では, 1 件 $20 \mathrm{ha}$
以上の住宅用地開発全体の面積で約 $20 \%$, それに伴 う移動土量で約 $35 \%$, 丘陵地が占めている.

5. 住宅用地開発状況を, 都市圈別あるいは市域 別に比較すると, 各地域の開発総面積は中心都市の 規模に左右されるが, その中地形別面積は, 各地域 の地形構成とその利用樣式に規制されるため, 開発 に伴う広域土量移動速度は, 都市の規模の大小とは 異なり，たとえば仙台・広島・鹿児島・那覇などで 比較的大きな值をとる.

このような直接的な地形改変規模・様式の変化に 加えて, 改変中や改変完了後の諸々の環境変化につ いて, 本稿で行なったものと比較検討しうるディメ ンジョンの指標が求められれば, 大規模土地改変現 象の全体像とその地域的・時代的変化が把握できる. それはさらに, 第 I 章で述べた枠組みに従って, 社会・経済状況の変化（たとえば高度経済成長, 第 1 次オイルショックなど), 政策の変遷 (とくに農用 地開発とその関連現象の場合), 建設技術の進歩 (と くに大型土木機械の普及) などの「人工地形形成要 因の変化」と関連づけて解䣋される. その中で, 同 ビ地形・地質特性（たとえば新第三系や下部更新統 からなる丘陵地)が，ある利用目的(たとえば住宅用 地）にとってもつ意味が, 時代によって大きく変化 すること(たとえぱTamura, 1976; 田村，1977)な ども，明らかになるであろう．また，災害の時代的 変質(たとえば西川，1958)などを論じる際の裏づけ 資料としても活用できるであろう.

本稿は，筆者ら 3 人による「大規模土地改変の全国的 趨勢と地域的事例」(1981 年度秋季学術大会シンポジウ 厶講演) と, 筆者の 1 人, 田村による「人工地形研究に おける大規模土地改変のとらえ方」(1982 年度春季学術 大会研究委員会講演) とを骨子とし, さらに資料の補訂 を行なって執筆したものである．本研究の一部に昭和 $54 \cdot 55$ 年度文部省科学研究費総合研究A「大規模土地改 変に伴う環境変化の比較研究」(研究代表者 : 門村 浩, 課題番号438032)を使用した. 本稿で用いた資料には同 総合研究成果報告書(門村，1981)に収録したものが含ま れている.

本研究遂行にご協力いただいた，門村 浩主查(北海 
道大)をはじめとする日本地理学会人工地形作業 グルー プの方々, とくに日下雅義(立命館大), 吉津直樹 (下関 市立大), 松田磐余・武内和彦(東京都立大), 赤木祥 彦 (福岡教育大), 今川俊明 (北海道大)の諸氏, ならびに資 料収集の際にお世話になった関係各機関の方々，とくに 粐倉克幹 (国土庁), 相場瑞夫 (農林水産省), 府本礼司 (沖 縄県), 塩島由道(地域開発コンサルタンツ)の諸氏に, 深く感謝する.

(投稿 1982年 9 月 3 日) (受理 1983年1月 8 日)

\section{注}

1) Haigh (1978) より引用.

2) その多くは man-induced landforming processesで，造成斜面の小規模な土壌侵食やそれに付 随する排水溝の埋積, 造成宅地面の排水不良など の日常的環境問題から，数年以上にわたって進行 する盛土平坦面の不等沈下，10年に 1 度くらいの 大雨で起きる盛土斜面，あるいは造成地に接する (半)自然斜面の表層崩壊，および造成がもたらす 流出量・流出速度の增大による下流部での汇濫激 化などの，いわば非日常的環境問題，さらには 100 年に 1 度くらいの大地震による盛土斜面の大 崩壊や切土地・盛土地境界での諸現象といった, 著しく非日常的な環境問題まで多岐にわたる(田 村, 1980; Tamura and Takeuchi, 1980).

3）その一部は田村 (1982)でも紹介した.

4）以下, 地形のスケール分けはTamura (1980)に 従う.

5）たとえば，1978年宮城県沖地震で白石市寿山第 4 団地に発生した盛土地の大崩壊（田村ほか, 1978)など

6）地形改変状況が端的に読みとれるような形で, そのような一次資料が一元的に集積・集計されて いるようなことはない。ただし，宅地造成等規制 法による宅地造成工事規制区域では，同区域指定 後の宅地造成工事 1 件ごとの面積・切土量・盛土 量などを, 都道府県または市の担当部課に提出さ れた工事認可申請書から知ることができる。

7）たとえば，同じ面積の工業用地開発でも，何本 もの尾根と谷とを含む丘陵地を対象とする場合と， 開析の進んでいない台地で行なわれる場合とでは, 地形改変の様式も規模も大きく異なることは自明 である.『工業統計表 用地・用水編』（1961年以 降)には都道府県別・産業中分類別の「用地取得 面積」が，その用地の以前の用途別に掲載されて いるが，これから地形改変状況を推測するには， いくつかのかなり乱暴な仮定を必要とする.
8）阪口・大森 (1981)は, 多摩丘陵大栗川流域につ いて，新・旧の 2.5 万分の 1 地形図に 1 辺 $5 \mathrm{~mm}$ の メッシュをかけて計測した高度分散量の変化から， 改変状況の大要とその地域的な違いを読みとろう とした。これは, 土工量, あるいは後述の移動土 量と直接関連づけない相対的な数值としては, 改 変規模の量的指標になりうる.

9）関東地方を例にとると，1974年現在，山地の約 $90 \%$ が森林 (その半分弱が人工林), 丘陵地の約 $1 / 3$ が二次林, 台地の約半分と低地の約 $2 / 3$ が耕地 (それぞれ主として畑地と水田) である（環境庁， 1976).

10）たとえば, 神奈川県団地立地調査報告, 大阪府 住宅・宅地開発状況図・一覧表など.

11）距離圈の設定については第III章-2)で述べる.

12) 中地形別にみると, 比較的小規模な住宅用地開 発は低地にやや多いようである.

13）この調查では，それぞれ一定面積以上の農用地， ゴルフ場, 別荘用地, 工場用地, 住宅用地, およ びレクリエーション用地の開発について, 地形・ 地質などの自然条件や災害発生の有無を含む，か なり多数の項目が調査・集計されている.しかし， 調査対象は, 上記の各種用地を県ごとに規模の順 に10件選び出したものなので，これを単純に集計 しても全国的傾向は求められない。

14）『農用地開発事業総覧』(1969), 『北海道開発局 農業水産部所管事業個所図』(1978)，『土地改良 の全容』(1979)など.

15）関連法令の施行は1961年.

16） 1975 年以後，各県で土地利用動向調査が実施さ れ, 用途別・事業種別に開発地のリスト（面積・ 着工年次など明記）と，各開発の位置を示した地 図(縮尺 20 万分の 1 程度)とが作成されている.こ れと土地分類図とを重ねあわせれば，各種用地の 開発面積を地形・地質別に再集計することができ よう.また，この土地利用動向調查結果が，将来 国土数值情報に取り入れられれば，25ha または $100 \mathrm{ha}$ 程度を単位とするスケールで, 地形別開発 面積を効率的に求められるようになるであろう. 現行の国土数值情報システムには土地利用の項目 があるが，改訂の際旧データを消去してしまうの で，土地利用転換状況の把握には利用できない.

17）山地・丘陵地・台地に含まれている谷底などに 立地するものを考慮すれば，おそらく $95 \%$ 以上。

18）正井・佐藤 (1982) は, 全国の市街地の地形的立 地条件を地形別面積比で表示するにあたり，「こ の程度のスケール（原則として 5 万分の 1 図上で 判読できる程度の精度）の調查では, たとえば台 
地と緩傾斜の丘陵地とを区分する意味があまりな いと判断」して，「低地と台地以上とに 2 分した」 が, この処置は, 市街化に伴う地形改変の規模 ・ 様式が台地と丘陵地とで大きく異なることを考え れば，妥当とはいい難い。

19）第 7 図に示した以外に，1961年以前に着工され てその後も工事が継続された大規模干拓が，東 北・関東・九州あわせて約 $70 \mathrm{~km}^{2}$ ある.

20) 今川俊明の収集資料 (『大規模土地改変に伴う環 境変化の比較研究』報告書所収)による.

21) 日下雅義の収集資料(『大規模土地改変に伴う環 境変化の比較研究』報告書収集）に追補したもの をもとに図化.

22）名古屋 $30 \mathrm{~km}$ 圈では，60年代前半に着エされた 1 件 $20 \mathrm{ha}$ 以上の住宅用地開発は, 台地上の 1 件 のみ (56 ha)である.

23）物質移動距離は, 人工改変によるものの方が自 然の削剝の場合より小さいことが多いので, 仕事 量の地域ごとの平均值のようなディメンジョンを もつ量で比較すれば, 人工改変と自然の削剝との 違いは，ここに示したものより小さくなると考え られる。

24） 1 件 20 ha 以上の開発総面積で表わすと， 1965 年から1979年の間の合計は $4,654 \mathrm{ha}$ となり, 規模 の小さい開発総面積はそれ程小さくなく,これに 基づいて推定した広域土量移動速度は, $2.7 \times 10^{3}$ $\mathrm{m}^{3} / \mathrm{km}^{2} \cdot \mathrm{y}$ となる.

25）Kadomura (1980)は，主として『国土利用白書 1977年版』の土地利用転換面積に基づき，各種開 発に伴う土地改変が最も活発であった1970〜1972 年の全国の年平均移動土量を, 約 $1.5 \times 10^{9} \mathrm{~m}^{3} / \mathrm{y}$ と推定している. これは全国平均の広域土量移動 速度に換算して約 $4.9 \times 10^{3} \mathrm{~m}^{3} / \mathrm{km}^{2} \cdot \mathrm{y}$ となり，後 述の道路・鉄道その他の開発による分を含めても， 今回の推定值の $2 \sim 4$ 倍程度になる. 当時の改変 の激しさがうかがわれる。

26）たとえば，丘陵地の住宅用地開発で生じた切土 の一部が，工業用地造成のための海面埋立てに用 いられ，二重に計測されているようなこと.

\section{文 献}

赤木祥彦 (1980)：広島都市圈における宅地造成によ る地形の改変. 地学雑, 89, 348 360.

大石堪山 (1982)：水田造成による土地改変. 地理, 27-9, 32 42.

門村 浩編 (1981)：『大規模土地改変に伴う環境変 化の比較研究』昭和 $54 \cdot 55$ 年度文部省科学研究費 報告書, 233ページ.
門村 浩・山本 博 (1978)：土地改変に伴う加速侵 食一侵食の速さと沖縄島北部の事例—. 地学 雑, 87, $1 \sim 15$.

環境庁 (1976)：『緑の国勢調査一一自然環境保全調 查報告書—』401ページ.

小林 詢 (1978)：長野県におけるゴルフ場開発と地

形. 『小出 武先生古稀記念論文集』327 341.

斎藤光格 (1965) : 都市的土地利用の土地基盤. 地図, 3, $157 \sim 166$.

阪口 豊・大森博雄 (1981) : 多摩川流域の地形・地

質. 「環境科学」研究報告集, $29 \sim 51$.

武内和彦・吉岡慎一 (1982) : 東京大都市地域の宅地 開発に伴う地形改変. 総合都市研究 No. 15, 49 58.

田村俊和 (1977)：山・丘陵—丘陵地の地形とその 利用・改変の問題を中心に一一. 土木工学大系編 集委員会編：『土木工学大系 19地域開発論 (I), 地形と国土利用』彰国社, 1 73.

田村俊和 (1980) : 宅地開発と自然災害. 環境情報科 学, 9-3, 37 48.

田村俊和 (1982)：全国的にみた大規模地形改変の実 態. 地理, 27-9, 16 24.

田村俊和・阿部 隆・宮城豊彦 (1978)：丘陵地の宅 地造成と地震被害—1978年宮城県沖地震の被害 を例として一一. 総合都市研究, No. 5, 115〜131. 西川 泰 (1968)：日本に抢ける災害の変遷に関する 研究. 国立防災科学技術センタ一研究報告, 2, $1 \sim 20$.

正井泰夫・佐藤恒雄 (1982)：日本の市街地の地形的 立地条件. 筑波大学人文地理学研究, 6, 51 64.

Demek, J.(1973): Quaternary relief development by man. Geoforum, 15, 68 71.

Haigh, M. J.(1978): Evolution of slopes on artificial landforms, - Blaenavon, U. K. Res. Pap., 183, Dept. Geogr. Univ. Chicago, 293 p.

Kadomura, H.(1980): Erosion by human activity in Japan. GeoJournal, 4, 133 144.

Marsh, G.P.(1864): Man and nature; or, physical geography as modified by human action. Charles Scribner, New York, 650 p.; reprinted by Belknap Press of Harvard Univ. Press, Cambrdge, 472 p. (1965).

Sherlock, R.L.(1923): The influence of man as an agent in geographical change. Geogr. Rev., 61, 258 273.

Takeuchi, K., Yoshioka, S., and Fumoto, R. (1981): Land transformation on Okinawa Island, southwest Japan. Geogr. Rep. Tokyo Met- 
ropol. Univ., No. 16, 113 129.

Tamura, T.(1976): A preliminary study of historical anthropogeomorphology in the hills of Japan. Geogr. [Rep. Tokyo Metropol. Univ., No. 11, 163 176.

Tamura, T.(1980): Multiscale landform classification study in the hills of Japan : Part I device of a multiscale landform classification system. Sci. Repts. Tohoku Univ. Ser. 7 (Geogr.), 30, $1 \sim 19$.

Tamura, T.(1981) : Multiscale landform classification study in the hills of Japan:Part II application of the multiscale landform classification system to pure geomorphological studies of the hills of Japan. Sci. Repts. Tohoku Univ. Ser. 7 (Geogr.), 31, 85 154.
Tamura. T. and Takeuchi, K.(1980): Land characteristics of the hills and their modification by man - with special reference to a few cases in the Tama Hills, west of Tokyo. Geogr. Repts. Tokyo Metropol. Univ., No.14/15, 49 94.

Twidale, C.R.(1968): Anthropogenetic influence in geomorphology. Fairbridge, R. W. ed.: Encyclopedia of geomorphology. Reinhold, New York, 15 18.

Zapletal, L.(1973): Neprime antropogenni geomorfologicke procesy a jejicj vliv na zemsky povrch. Acta Univ. Palackianae Olomoucensis. Fac. Rerum Naturalium No. 42, Geogr. Geol. 13, 239 261.

\section{A NATIONAL SUMMARY RECENT TRENDS OF LARGE-SCALE LANDFORM-TRANSFORMATION IN JAPAN}

\section{Toshikazu TAMURA*, Hiroshi YAMAMOTO** and Shin'ichi YOSHIOKA***}

Large-scale landform transformations for various purposes of land developments have been recently active in Japan. They have required the researchs from the viewpoint of anthropogenic geomorphology which contains both man-made and man-induced landforms and related phenomena in its scope. This paper reveals the recent trends of the change in types of landform utilized and estimates the magnitude of man-made landforming processes in the intensely developed lands in Japan.

Because the statistics showing the actual states of landform transformation have not been sufficiently prepared yet, the estimation of magunitude of artificial landforming processes in this study progresses inevitably in a felicitous combination of selected detailed surveys and effective generalization. First, landform modification types and magnitude are investigated with the aid of very large-scale scheme drawings etc. at the small number of typical development sites for each purpose and in each type of landform. The area of development and the volume of artificially-removed earth provide the simple indices of landformmodification magnitude. The greater volume between artificially cut material and filling

Geographical Review of Japan $\mathbf{5 6 - 4} 223 \sim 2421983$
* College of General Education, Tohoku University.

** Graduate School of Environmental Science, Hokkaido University.

*** Graduate Student, Tokyo Metropolitan University. 
one is used to represent the volume of artificiallyremoved earth in the site because most of earth cut from higher location is usually applied for filling in the lower location within the same development site except for ones in the flat lowlands and the reclaimed lands. The normal depth of surface disturbance is defined as the average of the ratio of the above volume to area of the site for both every development purpose, e. g. residential, industrial, agricultural, etc., and every geomorphic location which is classified into the follwing four intermediate-scale geomorphic units: the lowlands (Holocene alluvial and coastal plains), the terraces (mostly of late-Pleistocene age), the hills (mostly composed of early-Pleistocene and/or Neogene deposits with mid-Pleistocene cover in part), and the mountains. The areas for several purposes of development sites, which are usually provided with administrative districts, are also retotalized according to these geomorphic units. The normal depth of surface disturbace and the total area of development, both of which are arranged according to the development purposes and the intermediate-scale geomor phic units, are applied for the estimation of the total volume of artificially-removed earth.

Some results of the estimation are as follows:

1. The land development for various purposes became very active around 1960 and has been advanced with distinct decrease in the mid-1970's. The trends correspond well with changes in the national-scale socio-economic activity.

2. The rapid increase of intense land-developments since 1960 has proceeded in concurrent with the remarkable changes in locational condition of landform for residential, agricultural, and industrial sites from the lowlands and terraces to the hills, and further to the mountains in the case of agricultural development. For instance, more than $40 \%$ (in area) of the newly-developed residential sites are located in the hills. Moreover very extensive area of golf courses, which may exceed the total area of residential development, has been developed during the same period and most of them are located in the hills.

3. The increase of development area and the changes in its locational condition of landform to the hills have caused distinct rise of artificially-removed earth volume. The total volume of earth removed artificially during 20 years since 1960 in Japan may reach the order of $10^{10} \mathrm{~m}^{3}$, which means 1 or $2 \times 10^{3} \mathrm{~m}^{3}$ of earth material has been removed annually from every $1 \mathrm{~km}^{2}$ area. It is equivalent o several tens to more than hundred times of natural denudation rate in the humid temperate hills in the simple comparison without taking the difference in distance of movement into consideration. About $3 \times 10^{9} \mathrm{~m}^{3}$ of earth material was removed by the development of large-scale residential sites larger than $50 \mathrm{ha}$ during the same period in Japan. About a third of the volume were removed in 5 years from 1970 and about a half was produced in the hills.

4. In several metropolitan areas the annual rates of artificial earth removal per unit area reach as about several to ten times as those of the national average. And the regional difference of the rates is closely related with the geomorphic environment of the area.

It is necessary for further progress of comprehensive land transformation study to investigate the subsequent environmental changes, most of which concern the man-induced landforming processes, with the aid of such indicies as ones applied in this study. 